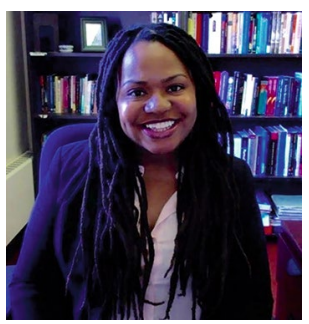

\title{
Prioritize care for a more resilient future
}

\author{
The pandemic is causing prolonged stress to our social connections, with major adverse \\ consequences to individual and societal health. As a group-living, cooperative species, we \\ need policies of communal care for a more equitable, resilient future, argues Robin Nelson.
}

Credit: Matthew Kroot

n March 2020, my university was entering the final month of the winter academic session when I began hearing news reports about a new deadly virus. Wuhan was under siege and Italy was 'shutting down'. What exactly did 'shutting down' mean in a modern capitalist economy when nearly everyone must work to live? I began to drop bits of information about coronavirus into my lectures hoping to provide some context for what students were hearing on social media. Finally, on March 12 th, I told my students, quite soberly, that we would not escape this virus untouched and it would most certainly disrupt our daily lives. That turned out to be our last in-person class meeting; our university moved to online instruction the next day.

In my research as a biological anthropologist, I use evolutionary theory to approach questions about individual engagement in social networks, familial interdependence, adult health, and child growth and development. As a parent of young children, I did not anticipate the emergence of a virus that would so integrate my research and home life. As stay-at-home orders were issued, few of us could imagine the long-term ramifications of these policies. Restaurants, schools and stores were closing by the hour. Many upper- and middle-class employees were being asked to work from home, while essential employees, who are often also low-wage workers, continued leaving their homes for work despite the increased risk of being infected with a virus about which we had a poor command of the basic transmission routes. In this new reality, parents were asked to do what we have never done: care for children in near-complete isolation, indefinitely. Questions loomed as to how we would manage this worldwide calamity. Were we entering an individualistic battle for goods and survival, or would we develop and utilize modes of mutual aid and communal care?

Anthropological research reveals that unpredictability and insecurity are two conditions for which primates, human and non-human alike, are not well suited. When non-human primates experience disruption in their social networks or changes in social status, they also often experience immunosuppression and systemic inflammation. This is particularly true for low-ranking or low-status individuals. Like our non-human primate relatives, humans also experience increased stress levels when our social and physical environment are unreliable or become unstable. When social connections are frayed due to a natural disaster, or any other prolonged stressor like divorce, job loss or death of a loved one, the deleterious mental and physical health effects begin to accumulate. Having now spent more than half of a calendar year restricting our movements outside of our homes; learning of colleagues, friends and family members who are sick or have passed away after contracting COVID-19; and in many cases, working from home while educating school-aged children, we are becoming a living case study of the effects of sustained stress on individual health.

This lockdown has had the effect of revealing societal fractures that were mostly ignored by those with the structural and institutional power to create better lives for everyday people. Because many families across the world live below the poverty line or paycheque to paycheque, an indefinite closing of entire employment sectors, coupled with remote learning for school-aged children, has forced many of these same families from their secure housing precisely when social distancing is most important. Essential workers have been required to continue serving an increasingly infected public and thus have been placed at increased risk of illness. Many professional women who were fortunate to not lose their jobs found themselves unable to maintain their workloads due to entrenched gender roles within the household. There is mounting evidence that women are leaving the job market at higher rates than their male counterparts. Barely manageable before the global pandemic, this cobbling together of care networks coupled with overwork has revealed itself to be far less resilient than what is needed in this emergent moment of global illness and fractured social relations.
Our evolutionary past may provide insight that allows us to imagine and create a more sustainable future. For the entirety of our evolution, humans have embraced cultural practices to both manage daily challenges and engage in creative pursuits. Additionally, it has been an evolutionary mandate to rely on other individuals, kin and non-kin alike, to help in raising children. Children have always belonged in and to their broader communities, as well as to their kin. Post-pandemic futures must acknowledge the central place of children in our society rather than treating them as simply an inconvenience that must be managed. Countries that actively avoided developing social safety nets in the forms of universal basic incomes, help with housing, national healthcare and childcare now bear witness to the need for these kinds of reforms as the most vulnerable members of society bear the brunt of the pandemic. Policies of communal care could mirror the attention and support that many of our ancestors provided one another in order to survive harsh environments, variable food availability and care of dependent members of the group. We see these very policies being enacted in countries like New Zealand that are handling the spread of the epidemic more successfully than other countries.

A society where community members are openly and admittedly interdependent will be better able to support itself when challenges arise. As we face growing economic inequality and ever-hastening climate change, we need to return to the core of our evolved humanity, one that prioritizes group living and cooperative behaviour to ensure our survival.

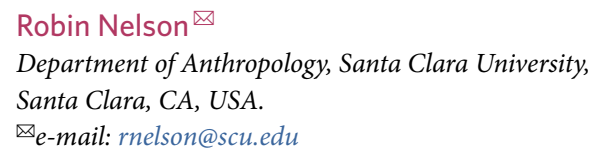

Published online: 8 January 2021

https://doi.org/10.1038/s41562-020-01037-w

\section{Competing interests}

The author declares no competing interests. 